\title{
Legacy of the International Year of Pulses
}

\author{
Teodardo Calles $^{1}$ (D) $\cdot$ Maria Xipsiti $^{2} \cdot$ Riccardo del Castello $^{3}$
}

Published online: 18 February 2019

(c) Springer-Verlag GmbH Germany, part of Springer Nature 2019

\begin{abstract}
The nutritional value of pulses for humans and the importance they have for improving sustainability of agricultural systems had been acknowledged by declaring 2016 as the International Year of Pulses (IYP). Awareness raising activities on the many benefits of pulses for food security, nutrition and agricultural systems were carried out worldwide by FAO and its partners, as well as by public and private sector entities, research centres, educational institutions and media. The IYP provided considerable impetus behind changing the perception of the general public about pulses. This perception change might be able to remodel the production and consumption patterns of pulses, which can further enhance the fight against poverty and malnutrition and increase the sustainability of agricultural systems. Additionally, the possible endorsement of a World Pulses Day could consolidate the momentum created by the IYP; however, the participation of different stakeholders is needed to create an enabling environment for the sustainable increase of pulse production and consumption.
\end{abstract}

Keywords Food security $\cdot$ Legume crops $\cdot$ Leguminosae $\cdot$ Nutrition $\cdot$ Sustainable agricultural systems

\section{Introduction}

Pulses are important food crops for large proportions of populations, particularly in developing countries where they are part of traditional diets and are often grown by small farmers. Having a low-fat content and richness in micronutrients, pulses can contribute to reduced risk of diet-related non-communicable diseases and to combating malnutrition and undernourishment.

Pulses have been an essential part of the human diet for centuries, yet their nutritional value is not generally recognized and is frequently underappreciated. For this reason the United Nations General Assembly declared 2016 as the International Year of Pulses (IYP) and mandated the Food and Agriculture Organization of the United Nations (FAO)

Teodardo Calles

teodardo.calles@fao.org

1 Plant Production and Protection Division (AGP), Food and Agriculture Organization of the United Nations, Rome, Italy

2 Nutrition and Food Systems Division (ESN), Food and Agriculture Organization of the United Nations, Rome, Italy

3 Partnerships and South-South Cooperation Division (DPS), Food and Agriculture Organization of the United Nations, Rome, Italy with its implementation in collaboration with UN organizations, governments, civil society organizations and other relevant stakeholders (UN 2013).

According to FAO (1994), pulses are a subgroup of legume crops harvested for dried grains, which can be used for both food and feed. Those legume species used for oil extraction (e.g. soybean; Glycine max [L.] Merr.), sowing purposes (e.g. alfalfa; Medicago sativa L.) and when used as vegetables (e.g. green pea; Pisum sativum L.), are not considered pulses. FAO (1994) classification listed more than 20 pulse species from which the most important are the following: common bean (Phaseolus vulgaris L.), mung bean (Vigna radiata [L.] R. Wilczek), mungo bean (Vigna mungo [L.] Hepper), chickpea (Cicer arietinum L.), cowpea (Vigna unguiculata [L.] Walp.), lentil (Lens culinaris Medik.), pigeon pea (Cajanus cajan [L.] Huth) and pea.

In terms of nutrition and food security, pulses are a good source of plant-based protein as well as dietary fibre, vitamins (e.g. B vitamins) and minerals such as iron, potassium, magnesium and zinc. Pulses have higher levels of protein, dietary fibre and minerals than all major cereals (FAO 2016a). As a source of proteins, pulses are particularly important because the amino acids contained in pulses complement the amino acids found in cereals. Balancing the diet with the right quantities of both pulses and cereals, the requirement of the amino acids essential for the human body 
can be met (Snapp et al. 2018). Eating pulses as a replacement for some animal protein also helps limit the intake of saturated fats and increases the intake of fibres helping to lower risk of cardiovascular disease (Ha et al. 2014; Halton et al. 2006). In fact, up to $80 \%$ of heart disease, stroke, type 2 diabetes and some cancers may be prevented by adopting and promoting healthy eating habits, in which pulses are included as they are an essential component for human nutrition (WHO 2008).

Pulses have a low Glycemic Index and have been shown to attenuate blood glucose (Lunde et al. 2011; Marinangeli and Jones 2012), a key factor in preventing diabetes. Consumption of pulses is additionally associated with satiety and thus helps in weight management (Jenkins and Jenkins 1995; Lunde et al. 2011). Therefore, increased production, consumption and utilization of pulses is relevant for addressing the triple burden of malnutrition, namely undernutrition, micronutrient deficiencies and obesity.

Nitrogen is an essential nutrient for increasing plant production (Wani et al. 1995). Currently, the energy-intensive Haber-Bosch process provides the reactive nitrogen required for agricultural fertilizers (Smil 2011). The plants uptake around $50 \%$ of the applied nitrogen fertilizers and the rest is loss to the environment, causing alterations of the terrestrial nitrogen cycle; therefore, there are environmental concerns, besides the emission of greenhouse gases (GHG), associated with the overuse of fertilizer (e.g. impaired water quality, enhanced invasive plant species) (Smil 2011; Rockström et al. 2016; Shibata et al. 2017). The most important advantage of pulses, and some other legumes, is their ability to utilize atmospheric nitrogen through a symbiosis with some bacteria (e.g. Rhizobium, Bradyrhizobium), which provide them the potential for improving the cycling of nitrogen. On the other hand, some pulses are able to mobilize soilbound phosphorous, thus enhancing the biological turnover of phosphorous (Nuruzzaman et al. 2005; Rose et al. 2010). Phosphorous is also an important nutrient for plants, which is mainly provided by inorganic fertilizers that are produced from non-renewable and relatively scarce phosphorite; therefore, closing local phosphorous cycles, for example by incorporating phosphorous efficient pulses, is an important step towards improving sustainability and resilience of agricultural systems (Sieveking et al. 2017). For the reasons mentioned above, the main advantage of including pulses in multiple cropping systems (e.g. agroforestry, crop rotations, intercropping) is that they provide different ecological services (e.g. increasing soil biodiversity, improving nutrient cycling) that make agro-ecosystems more resilient and improve its sustainability (Calles 2016).

There is clear evidence that global climate is changing and this change has been driven by the increase of anthropogenic greenhouse gas emissions; this situation is negatively impacting global agriculture by, for example, affecting plant phenology (e.g. earlier blooming) (Cutforth et al. 2007; Andrews and Hodge 2010; Bahl 2015). Recently, the threat of climate change has been perceived as a major challenge, leading governments around the world to sign an agreement-The Paris Agreement-where all nations have committed to undertake efforts to combat climate change and to keep the global temperature increment for this century under $2{ }^{\circ} \mathrm{C}$ (UN 2015). In this context, pulses have the potential to contribute to climate change mitigation and adaptation. As mentioned before, pulses have the ability to fix a significant amount of atmospheric nitrogen, up to $200 \mathrm{~kg} \mathrm{~N} / \mathrm{ha} \mathrm{per}$ season (Werner 2005). Since part of the nitrogen fixed by pulses remains in the soil, less nitrogen fertilizer is needed for subsequent or companion crops, thus helping to mitigate climate change by indirectly reducing GHG while decreasing dependency on the synthetic nitrogen fertilizer. The world's soils are considered to store the largest terrestrial pool of organic carbon (Amundson 2001). Carbon stocks in soil can be affected through changes in land use, and therefore, land use modification and management are considered particularly important components of any comprehensive strategy oriented to control GHG (Thomson et al. 2010; Deng et al. 2013). In this regard, many pulses might promote higher rates of soil carbon accumulation than cereals and grasses (Jensen et al. 2012) and also deep-rooted pulses are able to effectively sequester carbon and to redistribute it to deeper soil layers (Venkatesh et al. 2013). The carbon stored in a deeper soil profile is likely to be less susceptible to decomposition (Batjes and Sombroek 1997). Consequently, pulses can be considered climate-smart crops, which make an important contribution to mitigate climate change. On the other hand, pulses not only contribute to mitigate but also to adapt to climate change. Pulse crops are known for having a broad genetic diversity (Lewis et al. 2005), which is a very important attribute because this can be the basis for developing more climate-resilient varieties that can be adapted to future climate change scenarios. For example, temperatures are expected to rise, and therefore, heat stress will play an important role in plant production. However, we will be able to adapt our agricultural systems to climate change by selecting or breeding new varieties tolerant to high temperature because of the broad genetic diversity of pulses.

Despite the multiple benefits of pulses, its per capita consumption has declined in both developed and developing countries due to changes in dietary patterns/consumer preferences and failure of domestic production to keep pace with demographic growth in many countries (Alexandratos and Bruinsma 2012). This situation has been heightened because in many countries, especially in urban areas, pulses are underestimated and regarded as poor man's food (Miller 1980), the meat of the poor (Heiser 1990) or the meat of the countryside (Sperling 1992). However, nutritional and biological attributes of pulses may play a major role in reducing 
poverty and hunger and improving sustainability of agroecosystems, thus contributing towards achieving UN Sustainable Development Goals (SDGs), particularly SDG1 (no poverty), SDG2 (zero hunger), SDG3 (good health and wellbeing), SDG12 (responsible consumption and production) and SDG13 (climate action). Therefore, the IYP focused on raising public awareness of the multiple benefits of pulses for food and nutrition security and how pulses can help to improve the sustainability of agricultural systems.

\section{Implementing the International Year of Pulses}

The IYP was officially launched by the FAO DirectorGeneral, Jose Graziano da Silva on 11 November 2015 under the slogan Nutritious seeds for a sustainable future to emphasize the important role that pulses play in both human nutrition and sustainable agriculture. FAO hosted the secretariat of the IYP and facilitated its implementation under the guidance of an International Steering Committee (ISC) established in April 2015. The ISC was co-chaired by the Permanent Missions to the FAO of the Republic of Turkey and the Islamic Republic of Pakistan and was composed of representatives of FAO member countries, civil society, farmers' organizations, private sector, FAO technical divisions, research centres, International Fund for Agricultural Development (IFAD), World Food Programme (WFP) and Bioversity International. The IYP Secretariat, which was responsible for facilitating the implementation of the International Year, consisted of staff from FAO's Partnerships and South-South Cooperation Division (DPS), Plant Production and Protection Division (AGP), Nutrition and Food Systems Division (ESN), Trade and Markets Division (EST), Agricultural Development Economics Division (ESA) and the Office for Corporate Communications (OCC).

An action plan was prepared in collaboration with members of the IYP International Steering Committee to provide a set of guidelines, activities and events to be implemented during the year. The main activities of the Action Plan included:

- Regional and global consultations with pulses experts, policymakers, producer and trade organizations.

- Global and regional awareness campaigns-through online fora, web and social media.

- Preparing a global food composition database on pulses.

- Facilitating the writing of scientific publications.

The World Wide Web is currently one of the most effective channels for communicating information in a very fast way. For this reason, the IYP Secretariat, in collaboration with FAO's OCC, established a dedicated website for the IYP (http://www.fao.org/pulses-2016/en/).

The main objectives set by the IYP International Steering Committee were: (a) to raise awareness of the contribution of pulses to food security and nutrition, (b) to encourage all stakeholders, including national governments, to work towards improving productivity and increasing production of pulses and (c) to bring in focus the need for enhancing investment in research, development and extension services to achieve objectives $a$ and $b$.

\section{Results of the International Year of Pulses}

To promote the IYP and draw attention to its activities, FAO appointed one IYP Special Ambassador (SA) to each region, with the objective of supporting FAO in raising public awareness on the important contribution of pulses to food security, nutrition and sustainable agriculture. The Zimbabwean organic farmer and agriculture activist, Ms Elisabeth Mpofu, was appointed as the SA for Africa while for Europe the British writer, teacher and blogger, Ms Jenny Chandler, was appointed. The Canadian leading scientist, Dr Joyce Boye, became the SA for North America and Prof Kadambot Siddique was appointed for the Asia-Pacific Region. The Egyptian food stylist and entertainer, Ms Magy Habib, was selected to be the SA for the Near East and North Africa. The Mexican agronomist Ms Patricia Juárez Arango was appointed for Latin America and the Caribbean. The Special Ambassadors are prominent persons from their regions who offered their names, talents and time to reach out to different audiences in their professional capacities, through international events and media. The SAs were also involved in activities aimed at increasing opportunities for dialogue, participation and access to information on pulses, as well as motivate relevant stakeholders to take advantage of the IYP to encourage connections throughout the food chain, further global production of pulses, sustainable agriculture and address the challenges in the trade of pulses. The commitment of the SAs spans the globe as they actively participated in major international events such as the World Food Day celebrations, the Pan-African Grain Legume and World Cowpea Conference, the International Conference on Pulses, the Regional Dialogue in Latin America, among other events.

The overarching objective of the IYP was to raise awareness on the many benefits of pulses for food security, nutrition and agricultural systems by opening up opportunities for information exchange, improving mutual understanding through education and communication activities, promote appropriate policies and develop the necessary skills to enhance the production and trade of pulses. Awareness raising activities have been carried out worldwide by FAO and its partners, as well as by public and private sector entities, 
research centres, educational institutions and media. The IYP prompted a considerable response by governments, non-state actors, civil society and academia in terms of commitment and involvement in the organization of technical workshops, regional and national events and education programmes. Awareness was effectively raised among a variety of actors ranging from policymakers, pulses producers, processors and traders, restaurants and catering operators, health and nutrition practitioners, school children. The public at large has also been the focus of an intensive information and educational campaign through mass media (print, radio, TV, web), and face-to-face events such as cooking demonstrations, exhibitions, museum displays and international fairs. Pulses recipes and educational materials (i.e. fact sheets and infographics) have particularly attracted public attention and have been widely distributed on demand or downloaded from the IYP website.

The IYP website was launched in March 2015 and has been the main IYP communication tool. The website has been fully translated into seven languages (English, Spanish, French, Chinese, Russian, Arabic and Italian) and it has received a significant amount of page views (over a million) and its average traffic was 145\% higher than in any other previous international year facilitated by FAO. The Corporate FAO social media, with over 2 million followers, were used to promote the IYP including multimedia with interviews, videos and audio files. Numerous publications, leaflets and factsheets were released on the IYP key messages (i.e. nutrition, food security, health, climate change and biodiversity). Other complementary communication tools include: a blog with submissions from all around the world, weekly posts, educational materials for kids, recipes collection, a cookbook and infographics.

An important part of the communication success of the IYP has been clearly demonstrated by the figures reported by the Global Pulse Confederation (GPC), one of the main partners of the IYP. According to the GPC, more than 700 events were organized around the world and over 1 billion impressions were shared across hashtags @lovepulses and \#lovepulses. The number of people actively engaged with IYP social media exceeded 5 million. Around 2500 IYP related media articles were published and hundreds of recipes were exchanged/downloaded in the internet. IYP's videos were watched more than 4 million times and the GPC's website (http://www.pulses.org) on pulses has accumulated almost 4 million visits.

Two online discussions were held around the following main questions: Pulses are praised for their health, environmental and economic benefits. How can their full potential be tapped? and Pulses: innovations from the field to the cooking pot. Each online discussion was complemented by a webinar. The discussions stimulated an active exchange of ideas among experts, stakeholders and the general public at large by linking practical experiences and research. The participants stressed the importance of promoting production and consumption of pulses though improving seed systems and supporting the spreading of mixed cropping systems, facilitating access to markets and value addition, establishing stronger networks between the different actors in the pulse value chain, and the need for awareness raising on the health and nutrition benefits of pulses in addressing malnutrition and reducing the risk of non-communicable diseases. Summaries of the online discussions can be downloaded using the following links: http://www.fao.org/3/a-bl632e.pdf and http://www.fao.org/3/a-bq757e.pdf.

A series of face-to-face consultations were held in five regions (Africa: Marrakesh, Morocco-16/4/2016; Europe and Central Asia: Rome, Italy-12/10/2017; Asia and the Pacific: Ulaanbaatar, Mongolia-24/10/2016; Near East and North Africa: Cairo, Egypt-2/11/2016; Latin America and the Caribbean: Quito, Ecuador-29/11/2016) to engage pulses experts and relevant stakeholders in discussions around the issues in pulse production, consumption and trade. The IYP Dialogues highlighted context-specific issues and current challenges that the pulses sector is facing, as well as provided a forum for information exchange, networking and partnership opportunities among participants. An IYP Global Dialogue was held towards the end of 2016, where pulses experts came together to discuss the outcomes of the Regional Dialogues and to define and agree on a set of recommendations for follow-up by the IYP. The main recommendations of the Global Dialogue can be summarized as follows:

- Increase investment in basic and applied research to improve and stabilize pulse yields. However, research and development should be addressed to specific species and agro-ecological conditions.

- Support research oriented to develop new pulse products (e.g. pasta enriched with pulses).

- Increase investment in the development of machinery for small-holder farmers.

- Promote research on underutilized pulse species.

- Seed systems need to be improved to bridge the seed demand and supply.

- Strengthen national and international research on pulses and create synergies among ongoing initiatives (e.g. 10-Year Research Strategy for Pulse Crops, UN Decade of Action on Nutrition, Global Soil Partnership, International Treaty for Plant Genetic Resources for Food and Agriculture).

- Improve technical assistance and rural extension, including young professionals, on appropriate technology for small-holding pulse production.

- Policies and programmes should focus more on pulse producers, especially smallholders and young farmers, 
including support in terms of knowledge provision, improved inputs, credit, insurance, and participatory research.

- Preserve and apply indigenous knowledge production and agricultural practices.

- Incentivize the set-up and implementation of networks, roundtables, commissions and other inter-sectoral fora for discussions on pulses.

- Increase consumer awareness and knowledge on pulses through nutrition education, school nutrition/feeding programmes, public procurement schemes and pulses food labelling.

- Include pulses in nutrition policy and programmes.

- Promote the consumption of pulses (through celebrity chefs, restaurant chains, take-away, new recipes and pulse products).

Key publications were produced during the IYP to advocate on the importance of pulses. At the beginning of 2016 the book Pulses: Nutritious seeds for a sustainable future (FAO 2016a) was published. The book contains important technical information on pulses as well as pulse recipes from around the world. The International Year of Soils (IYS) was celebrated in 2015 to recognize that soils constitute the foundation of agricultural development (Vargas and Caon 2016). IYP maintained close links to the IYS events, and therefore, the publication Soils and pulses: Symbiosis for life (Altobelli et al. 2016) was produced to show that soils and pulses have several complementarities, which are important for sustainable agriculture. A special feature on pulses was included in the FAO's biannual report on global food markets Food outlook (FAO 2016b). This report presents information about how production, consumption and trade of pulses have developed in the last years. Since pulses by-products can be valuable sources of protein and energy for animals, available information on this subject was collated and synthesized in the book Pulses and their by-products as animal feed (Sharasia et al. 2017).

Another significant output of the IYP was the publication of the FAO/INFOODS global food composition database for pulses-including a user guide (Grande at al. 2017). A summarized version of this database is presented in Table 1. This database provides nutrient values for pulses and it is intended mainly for standard-setting purposes. However, lack of food composition data on some underutilized pulses such as African yam bean (Sphenostylis stenocarpa [Hochst. ex. A. Rich] Harms) and Scarlet runner bean (Phaseolus coccineus L.) was considered to be a notable shortcoming. Therefore, some efforts are needed to increase food composition data of underutilized pulse species.

\section{Impact of the International Year of Pulses and the way forward}

It is difficult to find an indicator to effectively measure the impact of the IYP soon after it finished. Statistics on production or consumption could be used for this purpose; however, FAO global database for agricultural commodities (http://www.fao.org/faostat/en) has a lag-time of 2 years. Therefore, it is too early to use these statistics for measuring IYP impact. Therefore, information on pulse crops was gathered from Google Scholar and the Web of Science and it is presented in Fig. 1. Based on the results of this Google Scholar search (Fig. 1), it seems that there has been an increasing interest in pulse crops in the last 10 years and the declaration of the IYP in 2013 triggered a further increase of publications related to pulse crops. The Web of Science results present a clearer picture of the impact of the IYP. The number of publications, including the word "pulses" in the title, increased tremendously during and after the IYP (Fig. 1). Another impact measure could be the figures presented by Statistics Canada (http:// www.statcan.gc.ca/) who reported the increment of more than $10 \%$ in the production area of chickpea and dry bean.

Definitely, a major success of the IYP was the considerable number of outreach activities, including educational and promotional events, organized worldwide in different languages and for different types of audiences. These have significantly contributed to raise the awareness and profile of pulses among all sectors of the population, as well as increase the level of collaboration and partnerships among key players. Thanks to this success, there has been a sound call to keep the momentum of the IYP alive and continue its awareness-raising activities beyond 2016. At the 2016 sessions of the FAO's Committee on Agriculture (COAG) and Committee on Commodity Problems (CCP), members acknowledged the contribution of pulses to food security, nutritional health and environmental protection. They encouraged governments to engage in public awareness events and to develop and implement appropriate policies for promoting the improvement of pulse production and consumption. The FAO Council in December 2016 endorsed the COAG and CCP reports and requested FAO member countries and all relevant stakeholders to take advantage of this momentum to continue the work on pulses, as well as to put forward proposals for concrete actions. The recommendations collected from the IYP Regional and Global Dialogues should be used to identify a series of actions to be undertaken.

In this regard, the Government of Burkina Faso has proposed to declare the annual observance of World Pulses Day on 10 February. The main objective of this initiative is to use the momentum created by the IYP and 
Table 1 Nutrient profile of different pulse species (expressed in $100 \mathrm{~g}$ of edible portion). Source: Grande et al. (2017)

\begin{tabular}{|c|c|c|c|c|c|c|c|c|}
\hline \multirow[t]{2}{*}{ Species } & \multirow[t]{2}{*}{ Protein $(g)$} & \multirow[t]{2}{*}{ Energy (kj) } & \multirow[t]{2}{*}{ Carbohydrate (g) } & \multirow[t]{2}{*}{ Dietary fibre (g) } & \multirow[t]{2}{*}{ Folate $(\mu \mathrm{g})^{\mathrm{a}}$} & \multicolumn{3}{|c|}{ Minerals (mg) } \\
\hline & & & & & & Iron & Magnesium & Zinc \\
\hline $\begin{array}{l}\text { Adzuki bean (Vigna angularis } \\
\text { [Wild.] Ohwi and H. Ohashi) }\end{array}$ & $4.4-7.3$ & $292-480$ & $11.1-18.3$ & $2.8-4.7$ & $76-110$ & $1-1.4$ & $28-39$ & $1.1-1.6$ \\
\hline $\begin{array}{l}\text { Bambara bean (Vigna subterranea } \\
\text { [L.] Verdc.) }\end{array}$ & $4.2-6.9$ & $307-504$ & $7.6-12.5$ & $6.5-10.8$ & & $0.6-0.9$ & $39-54$ & $0.4-0.6$ \\
\hline Broad bean (Vicia faba L.) & $5.3-9.1$ & $282-481$ & $8.3-14.9$ & $4-7.4$ & $30-45$ & $0.8-1.6$ & $29-43$ & $0.5-1.1$ \\
\hline Chickpea (Cicer arietinum L.) & $5.7-9.4$ & $432-674$ & $12.4-21.7$ & $4.1-11.2$ & $68-89$ & $1.4-3.2$ & $36-62$ & $0.8-1.4$ \\
\hline $\begin{array}{l}\text { Common bean (Phaseolus vul- } \\
\text { garis L.) }\end{array}$ & $4.5-9.5$ & $290-547$ & $8.8-18.4$ & $4.1-9.2$ & $39-110$ & $1.4-2.9$ & $33-79$ & $0.6-1.2$ \\
\hline $\begin{array}{l}\text { Cowpea (Vigna unguiculata [L.] } \\
\text { Walp.) }\end{array}$ & $4.5-8.8$ & $288-527$ & $8.9-19.1$ & $2.5-9$ & $79-120$ & $1.1-1.8$ & $30-58$ & $0.4-1.2$ \\
\hline $\begin{array}{l}\text { Hyacinth bean (Lablab purpureus } \\
\text { [L.] Sweet) }\end{array}$ & $5.6-8.9$ & $323-510$ & $10.7-16.9$ & $3.9-6.2$ & {$[3-4]$} & $1.4-1.9$ & $101-136$ & $1.4-1.9$ \\
\hline Lentil (Lens culinaris Medik.) & $5.7-11.3$ & $314-588$ & $10.4-20$ & $2.7-6.4$ & [12-29] & $1.5-2.7$ & $15-32$ & $0.8-1.5$ \\
\hline Lima bean (Phaseolus lunatus L.) & $4.8-8.4$ & $307-532$ & $10.4-18$ & $4.4-7.6$ & $50-79$ & $1.5-2.2$ & $41-60$ & $0.6-1$ \\
\hline $\begin{array}{l}\text { Lupine (different Lupinus L. spe- } \\
\text { cies) }\end{array}$ & $12.8-17.7$ & $535-586$ & $2-6.4$ & $13.9-18.2$ & $77-79$ & $1.5-3.1$ & $59-102$ & $1.1-2.7$ \\
\hline $\begin{array}{l}\text { Mung bean (Vigna radiata [L.] R. } \\
\text { Wilczek) }\end{array}$ & $4.8-9.1$ & $319-514$ & $10.8-18.4$ & $3.2-6.4$ & $80-110$ & $0.9-1.4$ & $33-58$ & $0.4-0.9$ \\
\hline $\begin{array}{l}\text { Mungo bean (Vigna mungo [L.] } \\
\text { Hepper) }\end{array}$ & $5.1-7.7$ & $287-431$ & $9.1-13.7$ & $4.2-6.5$ & {$[21-29]$} & $1.5-2$ & $41-56$ & $0.7-0.9$ \\
\hline $\begin{array}{l}\text { Moth bean (Vigna aconitifolia } \\
\text { [Jacq.] Maréchal) }\end{array}$ & $6.8-10.9$ & $393-629$ & $13.1-20.9$ & $4.2-6.8$ & $93-150$ & $1.7-2.8$ & $46-74$ & $1-1.6$ \\
\hline Pea (Pisum sativum L.) & $4.1-9.5$ & $290-614$ & $9-24$ & $2.8-9.2$ & {$[17-43]$} & $0.9-1.9$ & $20-38$ & $0.6-1.2$ \\
\hline $\begin{array}{l}\text { Pigeon pea (Cajanus cajan [L.] } \\
\text { Huth) }\end{array}$ & $6.4-9.7$ & $402-562$ & $12.4-17.8$ & $6.5-9.8$ & $59-75$ & $1.6-2.5$ & $37-57$ & $0.9-2.2$ \\
\hline $\begin{array}{l}\text { Rice bean (Vigna umbellata } \\
\text { [Thunb.] Ohwi and H. Ohashi) }\end{array}$ & $4.3-7$ & $298-494$ & $11.4-19.3$ & $3-5.6$ & [15-23] & $1.4-1.9$ & $45-64$ & $0.6-0.9$ \\
\hline
\end{tabular}

Samples were boiled and analyzed both without discarding the water and drained

${ }^{a}$ Values in squared brackets are considered by original authors of low quality

Fig. 1 Number of publications including the word "pulses" in the title (search restricted to Agriculture multidisciplinary, Agronomy, Nutrition dietetics and Plant sciences categories) and results using the search term "pulse crops" retrieved from the Web of Science and Google Scholar, respectively, during the last 10 years

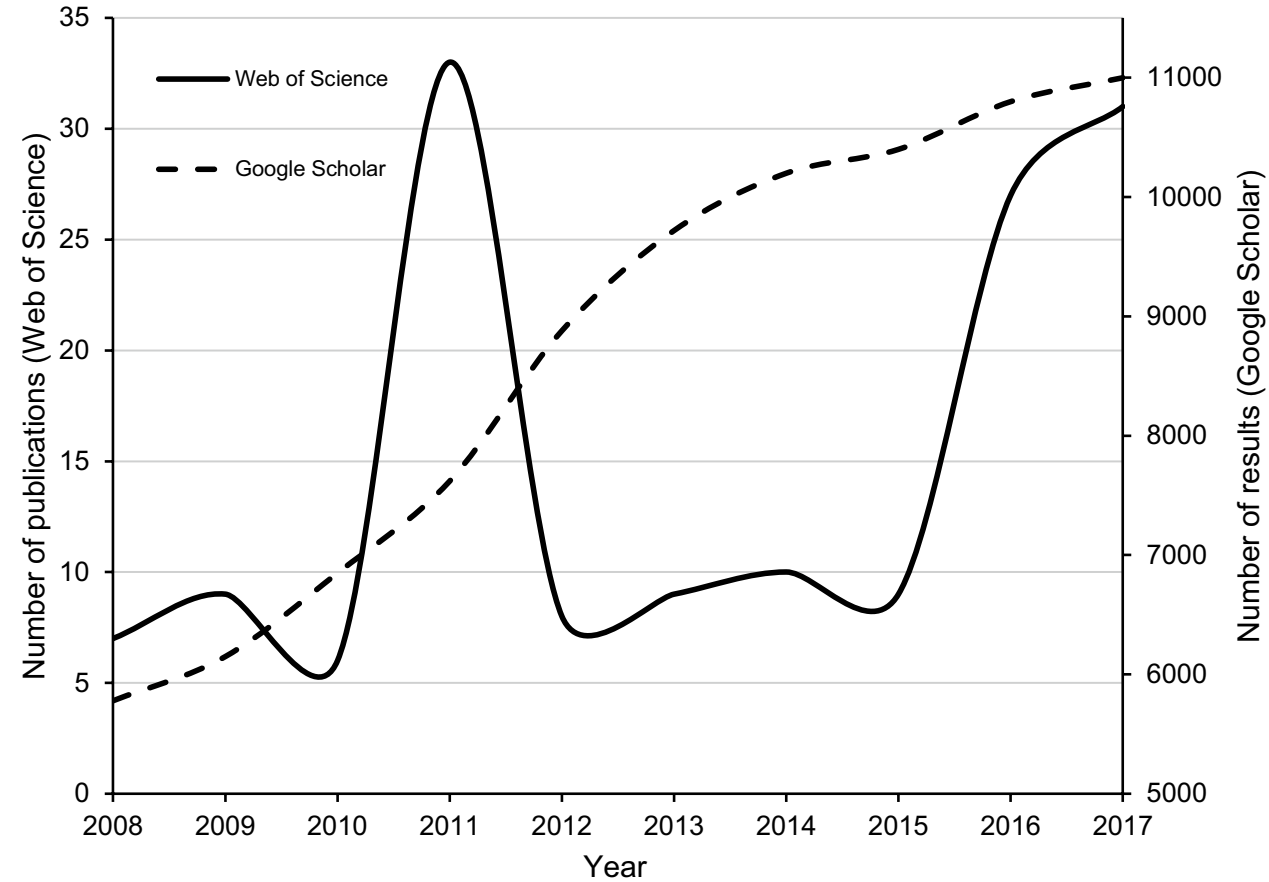


continue raising awareness of the contribution of pulses to food security, nutrition and sustainability of agricultural systems.

FAO's technical divisions are also working towards strengthening the programme on pulses. More specifically, in response to recommendations of the 155th FAO Council and based on the results of the consultations held during the IYP, FAO is proposing: (a) to establish a Pulses Action Network: an informal coalition of countries aimed at advocating for the establishment of policies and legislations on pulses which should allow the exchange of practices, highlighting successes and providing mutual support to accelerate implementation; (b) to facilitate the writing of publications on underutilized pulse species: for promoting a number of pulse species of minor relevance at the international level but which can be useful for specific niches because of their adaptation to marginal environmental conditions; (c) to revise FAO's pulses statistics: FAO pulse classification system includes some aggregated categories (i.e. dry bean, lupins and pulses nes). The aggregated nature of these categories make it difficult to detect trade trends of specific species; therefore, disaggregating these categories will help to improve the FAO's classification.

\section{Conclusions}

The IYP built up an important momentum that has changed the perception of the general public about pulses. This perception change might be able to remodel production and consumption patterns of pulses which can further enhance the fight against poverty and malnutrition and increase the sustainability of agricultural systems. Activities and events conducted during the IYP were organized by actors of different sectors (e.g. individuals, NGOs, governments, research institutions, private sector) which clearly demonstrated that participation of all individuals/institutions is a pre-requisite to make global events, such as the IYP, a successful story. It also became clear that collaboration between public and private sectors was a key parameter for the success of the IYP. Last but not least, advocacy activities organized during the IYP provided a unique opportunity to place pulses at the centre of the debate which might subsequently encourage governments to create an enabling policy environment, including the provision of incentives, for increasing the production of pulses.

Acknowledgements Implementation of the activities included in the IYP Action Plan was possible due to the financial support of the Ministry of Food, Agriculture and Livestock of the Republic of Turkey, International Fund for Agricultural Development, Global Pulse Confederation and Fertitecnica Colfiorito.
Disclaimer The views expressed in this publication are those of the authors and do not necessarily reflect the views or policies of the Food and Agriculture Organization of the United Nations.

\section{References}

Alexandratos N, Bruinsma J (2012) World agriculture towards 2030/2050: the 2012 revision. Food and Agriculture Organization of the United Nations, Rome

Altobelli F, Amanullah K, Benedetti A, Calles T, Caon L, Charrondiere R, Giri SP, Grande F, Muthuraman RP, Pisante M, Pramar B, Vargas R, Verma D, Vishwakarma AK, Wiese L, Xipsiti M (2016) Soils and pulses: symbiosis for life. Food and Agriculture Organization of the United Nations, Rome

Amundson R (2001) The carbon budget in soils. Annu Rev Earth Planet Sci 29:535-562

Andrews M, Hodge S (2010) Climate change, a challenge for cool season grain legume crop production. In: Yadav SS, McNeil DL, Redden R, Patil SA (eds) Climate change and management of cool season grain legume crops. Springer, Dordrecht, pp 1-9

Bahl PN (2015) Climate change and pulses: approaches to combat its impact. Agric Res 4(2):103-108

Batjes NH, Sombroek WG (1997) Possibilities for carbon sequestration in tropical and subtropical soils. Glob Change Biol 3(2):161-173

Calles T (2016) Preface to special issue of leguminous pulses. Plant Cell Tissue Cult 127(3):541-542

Cutforth HW, McGinn SM, McPhee KE, Miller PR (2007) Adaptation of pulse crops to the changing climate of the Northern Great plains. Agron J 99(6):1684-1699

Deng L, Sweeney S, Shangguan Z (2013) Long-term effects of natural enclosure: carbon stocks, sequestration rates and potential for grassland ecosystems in the Loess Plateau. Clean Soil Air Water 42(5):617-625

FAO (Food and Agriculture Organization of the United Nations) (1994) Definition and classification of commodities, 4. Pulses and derived products. http://www.fao.org/es/faodef/fdef04e.htm. Accessed 19 Apr 2017

FAO (2016a) Pulses: nutritious seeds for a sustainable future. Food and Agriculture Organization of the United Nations, Rome

FAO (2016b) Food outlook: biannual report on global food markets. Food and Agriculture Organization of the United Nations, Rome

Grande F, Stadlmayr B, Fialon M, Dahdouh S, Rittenschober D, Longvah T, Charrondiere UR (2017) FAO/INFOODS global food composition database for pulses, version 1.0. Food and Agriculture Organization of the United Nations, Rome

Ha V, Sievenpiper JL, Souza RJ de, Jayalath VH, Mirrahimi A, Agarwal A et al (2014) Effect of dietary pulse intake on established therapeutic lipid targets for cardiovascular risk reduction: a systematic review and meta-analysis of randomized controlled trials. Can Med Assoc J 186(8):E252-E262

Halton TL, Willett WC, Liu S, Manson JE, Albert CM, Rexrode K, Hu FB (2006) Low-carbohydrate-diet score and the risk of coronary heart disease in women. New Engl J Med 35(19):1991-2001

Heiser CB (1990) Seed to civilization: the story of food. Harvard University Press, Cambridge

Jenkins DJ, Jenkins AL (1995) Nutrition principles and diabetes. A role for "Lente Carbohydrate"? Diabetes Care 18(11):1491-1498

Jensen ES, Peoples MB, Boddey RM, Gresshoff PM, HauggaardNielsen H, Alves BJR, Morrison MJ (2012) Legumes for mitigation of climate change and the provision of feedstock for biofuels and biorefineries. A review. Agron Sustain Dev 32(2):329-364

Lewis G, Schrire B, Mackinder B, Lock M (2005) Legumes of the world. The Royal Botanic Gardens, Kew 
Lunde MSH, Hjellset VT, Holmboe-Ottesen G, Høstmark AT (2011) Variations in postprandial blood glucose responses and satiety after intake of three types of bread. J Nutr Metab. https://doi. org/10.1155/2011/437587

Marinangeli CPF, Jones PJH (2012) Pulse grain consumption and obesity: effects on energy expenditure, substrate oxidation, body composition, fat deposition and satiety. Br J Nutr 108(S1):S46-S52

Miller DS (1980) Man's demand for energy. In: Blaxter K (ed) Food chains and human nutrition. Applied Science Publishers, London, pp 23-50

Nuruzzaman M, Lambers J, Bolland MDA, Veneklaas EJ (2005) Phosphorous benefits of different legume crops to subsequent wheat grown in different soils of Western Australia. Plant Soil 271(1-2):175-187

Rockström J, Williams J, Daily G, Noble A, Matthews N, Gordon L, Wetterstrand H, DeClerck F, Shah M, Steduto P, Fraiture C de, Hatibu N, Unver O, Bird J, Sibanda L, Smith J (2016) Sustainable intensification of agriculture for human prosperity and global sustainability. Ambio 46(1):4-17

Rose TJ, Hardiputra B, Rengel Z (2010) Wheat, canola and grain legume access to soil phosphorus fractions differs in soils with contrasting phosphorus dynamics. Plant Soil 326(1):159-170

Sharasia PL, Garg MR, Bhanderi BM (2017) Pulses and their byproducts as animal feed, Calles T, Makkar HPS (eds). Food and Agriculture Organization of the United Nations, Rome

Shibata H, Galloway JN, Leach AM, Cattaneo LR, Noll LC, Erisman JW, Gu B, Liang X, Hayashi K, Ma L, Dalgaard T, Graversgaard M, Chen D, Nansai K, Shindo J, Matsubae K, Oita A, Su M-C, Mishima S-I, Bleeker A (2017) Nitrogen footprints: Regional realities and options to reduce nitrogen loss to the environment. Ambio 46(2):129-142

Sieveking A, Weber H, Riewerts B, Böhme M (2017) Towards a sustainable use of phosphorous: a transdisciplinary scenario analysis for the administrative Distric of Lüneburg, Germany. GAIA Ecol Persp Sci Soc 26(1):34-42

Smil V (2011) Nitrogen cycle and world food production. World Agric 2:9-13

Snapp S, Rahmanian M, Batello C (2018) Pulse crops for sustainable farms in sub-Saharan Africa, edited by Calles T. Food and Agriculture Organization of the United Nations, Rome
Sperling L (1992) Farmer participation and the development of bean varieties in Rwanda. In: Moock JL, Rhoades RE (eds) Diversity, farmer knowledge and sustainability. Cornell University Press, Ithaca, pp 96-112

Thomson AM, Izaurralde RC, Smith SJ, Clarke LE (2010) Integrated estimates of global terrestrial carbon sequestration. Glob Environ Change 18(1):192-203

UN (United Nations) (2013) Resolution 68/231. International Year of Pulses, 2016. http://www.un.org/en/ga/. Accessed 18 Apr 2017

UN (2015) The Paris Agreement. Process and Meetings. United Nations Framework Convention on Climate Change. http://unfcc c.int/paris_agreement/items/9485.php. Accessed 26 Apr 2018

Vargas Rojas R, Caon L (2016) The international year of soils revisited: promoting sustainable soil management beyond 2015. Environ Earth Sci 75:1184

Venkatesh MS, Hazra KK, Ghosh PK, Praharaj CS, Kumar N (2013) Long-term effect of pulses and nutrient management on soil carbon sequestration in Indo-Gangetic plains of India. Can J Soil Sci 93(1):127-136

Wani SP, Rupela OP, Lee KK (1995) Sustainable agriculture in the semi-arid tropics through biological nitrogen fixation in grain legumes. Plant Soil 174(1-2):29-49

Werner D (2005) Production and biological nitrogen fixation of tropical legumes. In: Werner D, Newton WE (eds) Nitrogen fixation in agriculture, forestry, ecology and the environment. Springer, Dordrecht, pp 1-13

WHO (World Health Organization) (2008) Action plan for the global strategy for the prevention and control of non-communicable diseases. http://whqlibdoc.who.int/publications/2009/9789241597 418_eng.pdf. Accessed 28 Mar 2018

Publisher's Note Springer Nature remains neutral with regard to jurisdictional claims in published maps and institutional affiliations. 